Received: 7 March 2019, Revised: 15 March 2019

Accepted: 5 April 2019, Published: 28 April 2019

Available online at: http://e-journal.unair.ac.id/index.php/IMHSJ

\title{
KETIDAKSIAPAN BIDAN DALAM PERENCANAAN KEHAMILAN PADA WANITA DENGAN HIV/AIDS DI PUSKESMAS KOTA SURABAYA
}

\section{UNPREPAREDNESS OF MIDWIVES IN PLANNING PREGNANCY IN WOMEN WITH HIV/ AIDS IN SURABAYA CITY HEALTH CENTER}

\author{
Amila Anasantrianisa ${ }^{1}$, Muhammad Ilham Aldika Akbar ${ }^{2}$, Pudji Lestari ${ }^{2}$ \\ 1. Program Studi Pendidikan Bidan, Fakultas Kedokteran, Universitas \\ Airlangga Surabaya \\ 2. Fakultas Kedokteran, Universitas Airlangga \\ Alamat korespondensi: \\ Jalan Mayjen Prof. Dr. Moestopo No.47 Surabaya \\ Email: amila.anasantrianisa@gmail.com
}

\begin{abstract}
Abstrak
Latar Belakang: HIV merupakan sejenis virus yang dapat menyebabkan turunnya kekebalan tubuh manusia. Pada wanita hamil dengan HIV mempunyai kemungkinan melahirkan anak dengan HIV. Dalam tugasnya, bidan mempunyai peran untuk melakukan pencegahan penularan HIV/AIDS dari ibu ke anak, termasuk melakukan perencanaan kehamilan terhadap wanita dengan HIV/AIDS. Penelitian bertujua untuk mengetahui kesiapan bidan dalam perencanaan kehamilan pada wanita dengan HIV/AIDS. Metode: Penelitian deskriptif observasional dengan pendekatan cross sectional. Besar sampel sebanyak 88 bidan yang bekerja di 12 puskesmas wilayah Surabaya. Teknik sampling dilakukan sesuai dengan daftar puskesmas yang telah diberikan oleh Dinas Kesehatan Kota Surabaya. Variabel dalam penelitian yaitu pengetahuan, sikap, dan kesiapan bidan dalam perencanaan kehamilan pada wanita dengan HIV/AIDS. Hasil: Didapatkan mayoritas bidan berusia 23-32 tahun (62,5\%) dan lama bekerja 1-10 tahun (71,6\%). Puskesmas yang memiliki layanan PMTCT sebanyak 11 puskesmas $(91,7 \%)$ dan 100\% puskesmas mempunyai lembar balik HIV/AIDS. Sebagian besar bidan mempunyai pengetahuan baik $(87,5 \%)$. Sebanyak $(48,9 \%)$ bidan memiliki sikap negative dan (53,4\%) bidan tidak siap dalam perencanaan kehamilan terhadap wanita dengan HIV/AIDS. Kesimpulan: Sebagian besar bidan tidak siap dan masih memiliki stigma negatif terhadap ODHA. Mayoritas bidan belum mengetahui keuntungan dan kerugian dari jenis persalinan pada ibu dengan HIV/AIDS serta belum mengetahui pemberian nutrisi pada bayi bagi ibu dengan HIV/AIDS.
\end{abstract}

Kata kunci: Kesiapan bidan, HIV/AIDS, perencanaan kehamilan

\section{Abstract}

Background: HIV is a type of virus that can cause a decrease in human immunity. In pregnant women with HIV it is possible to give birth to children with HIV. In their duties, midwives have a role to prevent HIV / AIDS transmission from mother to child, including pregnancy planning for women with HIV / AIDS. The study aimed to determine the readiness of midwives in pregnancy planning in women with HIV / AIDS. Method: An observational descriptive study with cross sectional approach. The sample size was 88 midwives who worked in 12 Puskesmas in Surabaya. The sampling technique was carried out according to the list of health centers that had been given by the Surabaya City Health Office. The variables in the study were the knowledge, attitudes, and readiness of midwives in pregnancy planning in women with HIV / AIDS. Results: The majority of midwives aged 23-32 years (62.5\%) and working duration 1-10 years (71.6\%) were obtained. 
Puskesmas that have PMTCT services are 11 health centers (91.7\%) and 100\% puskesmas have a back sheet of HIV / AIDS. Most midwives have good knowledge (87.5\%). As many as (48.9\%) midwives have a negative attitude and (53.4\%) midwives are not ready for pregnancy planning for women with HIV/AIDS. Conclusion: Most midwives are not ready and still have a negative stigma towards PLWHA. The majority of midwives do not yet know the advantages and disadvantages of the type of childbirth to mothers with HIV / AIDS and do not yet know the provision of nutrition to infants for mothers with HIV / AIDS.

Keywords: midwife readiness, $H I V / A I D S$, pregnancy

\section{PENDAHULUAN}

HIV atau Human Immunodeficiency Virus adalah sejenis virus yang menyerang sel darah putih yang menyebabkan turunnya kekebalan tubuh manusia (Kementerian Kesehatan RI, 2014). AIDS atau Acquired Immune Deficiency Syndrome adalah sekumpulan gejala penyakit yang timbul karena turunnya fungsi kekebalan tubuh yang disebabkan oleh infeksi HIV. Menurut laporan perkembangan HIV-AIDS Kementrian Kesehatan Indonesia hingga Desember 2017 tercatat 280.623 kasus HIV dan 102.667 kasus AIDS di Indonesia. Pada tahun 2017, Jawa Timur menempati posisi nomor satu sebagai provinsi yang melaporkan jumlah HIV terbanyak, yaitu sebesar 2.941 kasus kemudian diikuti oleh DKI Jakarta dengan 1.955 kasus (Kementerian Kesehatan RI, 2017). Pada tahun 2017 di Surabaya, ditemukan 672 kasus HIV dan 262 kasus AIDS. Di Indonesia, faktor risiko HIV/AIDS paling tinggi pada tahun 2017 yaitu dari Homosex sebesar 6.390 kasus. Namun, penularan HIV/AIDS melalui perinatal adalah masalah yang juga sangat penting untuk diperhatikan. Dari seluruh jumlah AIDS yang dilaporkan di Indonesia, faktor risiko perinatal mencapai 2.94\% (Kementerian Kesehatan RI, 2017).

Pencegahan penularan HIV dari ibu ke anak (PPIA) atau Prevention of Mother-to-Child HIV Transmission (PMTCT) merupakan intervensi yang sangat efektif untuk mencegah penularan tersebut. Upaya ini diintegrasikan dengan upaya eliminasi sifilis kongenital dan hepatitis, karena sifilis meningkatkan risiko penularan HIV di samping mengakibatkan berbagai gangguan kesehatan pada ibu dan juga ditularkan kepada bayi seperti pada infeksi HIV. Tujuan umum Program PPIA adalah mencegah penularan HIV dan sifilis dari ibu ke anak dan meningkatkan kualitas hidup ibu dan anak yang terinfeksi HIV dan sifilis dalam rangka menurunkan kejadian kasus baru HIV pada bayi dan kejadian sifilis 
kongenital (Kementerian Kesehatan RI, 2015). Program ini dapat dilaksanakan secara terintegrasi di setiap tingkatan layanan kesehatan dan dapat dilaksanakan oleh puskesmas dan jajarannya, rumah sakit, dan bidan praktik mandiri. Perencanaan kehamilan yang baik mampu menurunkan risiko penularan HIV/AIDS menjadi kurang dari 2\%. Perempuan dengan HIV memerlukan kondisi khusus yang aman untuk hamil, bersalin, nifas dan menyusui, yaitu aman untuk ibu terhadap komplikasi kehamilan akibat keadaan daya tahan tubuh yang rendah; dan aman untuk bayi terhadap penularan HIV selama kehamilan, proses persalinan dan masa laktasi. Bidan yang mana mempunyai posisi terdepan dalam membantu perencanaan kehamilan pada perempuan dengan HIV, dituntut untuk selalu siap dalam menjalankan tugasnya. Tujuan penelitian ini adalah mengetahui seberapa siap bidan membantu merencanakan kehamilan pada perempuan dengan HIV.

\section{METODE}

Tempat penelitian ini dilakukan di puskesmas Gading, puskesmas Keputih, puskesmas Klampis, puskesmas Mulyorejo, puskesmas Mojo, puskesmas Tanah Kali Kedinding, puskesmas Tenggilis, puskesmas Menur, puskesmas Pacar Keling, puskesmas Kali Rungkut, puskesmas Banyuurip, puskesmas Rangkah. Desain penelitian menggunakan penelitian deskriptif dengan metode cross sectional. Populasi pada penelitian ini adalah seluruh bidan yang bekerja di puskesmas Kota Surabaya. Teknik sampling yang digunakan adalah sesuai dengan daftar puskesmas yang telah dipilih oleh Dinas Kesehatan Kota Surabaya. Pengumpulan data menggunakan data primer dari kuesioner yang diisi oleh responden, yaitu bidan yang bekerja di puskesmas kota Surabaya. Analisis data pada penelitian ini menggunakan analisis secara deskriptif meliputi distribusi dan frekuensi dari masing-masing variable.

\section{HASIL DAN PEMBAHASAN}

\section{Tabel 1. Distribusi Responden Menurut Pengetahuan}

\begin{tabular}{lcc}
\hline \multicolumn{1}{c}{ Pengetahuan } & Frekuensi & Persentase $(\%)$ \\
\hline Baik $(\geq 75)$ & 77 & $87,5 \%$ \\
Rendah $(<75)$ & 11 & $12,5 \%$ \\
\hline Jumlah & 88 & $100,0 \%$ \\
\hline
\end{tabular}


Sebagian besar pengetahuan responden mengenai HIV/AIDS dan kehamilan adalah baik, yaitu sebesar 77 responden (87,5\%). Hal ini dapat dipengaruhi oleh sarana dan prasana pada puskesmas yang telah memadai dalam pelaksanaan layanan PMTCT. Adanya layanan PMTCT dan lembar balik pada puskesmas dirasa mampu meningkatkan kesadaran bidan untuk lebih mengetahui mengenai HIV/AIDS dan kehamilan pada ODHA. Berdasarkan analisis jawaban, responden yang memiliki pengetahuan baik memunyai latar belakang usia dan lama bekerja yang berbeda. Sehingga, pada penelitian ini tidak ada kaitan antara umur dan lama bekerja terhadap tingkat pengetahuan pada responden. Hasil penilaian pada kuesioner pengetahuan, terdapat 3 pernyataan yang mampu dijawab benar oleh $100 \%$ responden yaitu pernyataan "untuk mengetahui status HIV-AIDS seseorang harus melakukan tes darah", pernyataan "HIV-AIDS dapat dicegah dengan cara hanya memiliki satu pasangan tetap" dan pernyataan "pemakaian jarum suntik secara bersama”. Menurut (Kemenkes 2015), seseorang yang ingin mengetahui status HIV perlu dilakukan TIPK (tes HIV atas inisiatif pemberi pelayanan kesehatan dan konseling) yang mana langkah-langkah dari TIPK ini adalah pemberian informasi sebelum tes, pengambilan darah, penyampaian hasil tes, dan konseling. Menurut (U.S. Departement of Health and Human Sevices, 2017) mengenai langkah-langkah untuk mencegah terinfeksi HIV yaitu salah satunya adalah membatasi jumlah pasangan seksual. Berdasarkan pernyataan (Peters and Brooks, 2018) bahwa HIV dapat ditularkan salah satunya dengan cara pemakaian jarum atau suntik secara bersama. Dengan demikian, bidan di puskesmas wilayah Surabaya telah mengetahui mengenai cara mendeteksi HIV, pencegahan dan penularan infeksi HIV.

\section{Tabel 2. Distribusi responden menurut sikap}

\begin{tabular}{lcc}
\multicolumn{1}{c}{ Sikap } & Frekuensi & Persentase $(\%)$ \\
\hline Positif $(\geq 42)$ & 45 & $51,1 \%$ \\
Rendah $(<42)$ & 43 & $48,9 \%$ \\
\hline Jumlah & 88 & $100,0 \%$ \\
\hline
\end{tabular}

Sikap responden pada penelitian ini didapatkan mayoritas memiliki sikap positif $(51,1 \%)$. Namun, responden yang memiliki sikap negatif hampir mencapai 50\%. Hal ini menunjukkan bahwa masih banyak bidan yang memiliki stigma negative terhadap orang dengan HIV/AIDS dan kehamilan pada ODHA. Hasil 
penilaian pada kuesioner sikap, sebagian besar responden memilih jawaban sangat setuju (SS) dan setuju (S) pada pernyataan "perempuan dengan HIV/AIDS tidak boleh melahirkan pervaginam" dan "perempuan dengan HIV/AIDS tidak boleh memberikan ASI Eksklusif kepada bayinya". Menurut (Kemenkes, 2015) ibu dengan HIV boleh melahirkan pervaginam. Tujuan persalinan aman bagi ibu dengan HIV adalah menurunkan risiko penularan HIV dari ibu ke bayi, serta risiko terhadap ibu, tim penolong (medis/non-medis) dan pasien lainnya. Risiko penularan pada persalinan per vaginam dapat diperkecil dan cukup aman bila ibu mendapat pengobatan ARV selama setidaknya enam bulan dan/atau viral load kurang dari 1000 kopi/mm3 pada minggu ke-36. Menurut (Aishat, David and Olufunmilayo, 2015) pemberian ASI eksklusif mempunyai risiko penularan HIV lebih rendah daripada pemberian makanan campuran. Menurut (World Health Organization and UNICEF, 2016), ibu dengan HIV/AIDS boleh memberikan susu formula pada bayinya asalkan memenuhi syarat AFASS.

Tabel 3. Kesiapan Bidan

\begin{tabular}{lccccc}
\hline \multirow{2}{*}{ Kesiapan } & Frekuensi (\%) & \multicolumn{2}{c}{ Pengetahuan } & \multicolumn{2}{c}{ Sikap } \\
\cline { 3 - 6 } & & baik & rendah & positif & negatif \\
\hline Siap & $41(46,6 \%)$ & $41(100 \%)$ & 0 & $41(100 \%)$ & 0 \\
Tidak siap & $47(53,4 \%)$ & $36(76,6 \%)$ & $9(23,4 \%)$ & $4(8,5 \%)$ & $43(91,5 \%)$ \\
\hline Jumlah & $88(100 \%)$ & 77 & 9 & 45 & 43 \\
\hline
\end{tabular}

Sebagian besar bidan tidak siap dalam perencanaan kehamilan pada wanita dengan HIV/AIDS (53,4\%). Bidan dikatakan siap apabila memiliki nilai pengetahuan baik dan sikap positif. Menurut data yang telah didapatkan, bidan yang mempunyai pengetahuan baik belum tentu mempunyai sikap positif dan begitu pula sebaliknya. Berdasarkan identifikasi pengetahuan dan sikap responden, kesiapan bidan dapat dipengaruhi oleh masih banyaknya bidan yang memiliki sikap negatif. Perbandingan nilai sikap pada responden yaitu 45 responden memiliki sikap positif dan 43 responden memiliki sikap negatif. Menurut analisis jawaban, sikap negatif responden yang mempengaruhi kesiapan yaitu belum mengetahui keuntungan dan kerugian dari jenis persalinan pada ibu dengan HIV/AIDS dan responden juga belum mengetahui pemberian nutrisi pada bayi bagi ibu dengan HIV/AIDS. Hasil penelitian oleh (Sariningsih and Yogisutanti, 2015) yang dilakukan pada 30 orang bidan praktik mandiri di kota Bandung, menunjukkan hasil bahwa sebagian besar 
responden mempunyai pengetahuan dalam melakukan deteksi dini ibu hamil HIV AIDS dalam kategori baik (70\%). Penelitian (Rahmadona, Serudji and Erwani, 2014) mengenai perilaku bidan dalam pencegahan risiko penularan HIV/AIDS pada pertolongan persalinan normal di Kota Tanjungpinang, menjelaskan bahwa bidan akan berperilaku baik dalam pencegahan risiko penularan HIV/AIDS pada pertolongan persalinan normal apabila berpengetahuan baik, bersikap positif, memiliki motivasi tinggi, dilakukan supervisi serta didukung dengan sarana yang lengkap.

\section{SIMPULAN DAN SARAN}

Pada penelitian ini didapatkan sebagian besar responden memiliki pengetahuan yang baik dan sikap positif terhadap orang dengan HIV/AIDS dan kehamilan pada ODHA. Sebagian besar bidan di puskesmas kota Surabaya belum siap dalam melaksanakan perencanaan kehamilan pada wanita dengan HIV/AIDS.

Tenaga kesehatan diharapkan dapat mencari dan mempelajari lebih dalam lagi mengenai HIV/AIDS dan kehamilan pada ODHA, puskesmas dapat memberikan update ilmu mengenai HIV/AIDS dan penelitian ini diharapkan dapat dijadikan referensi yang relevan, membantu penelitian sejenis terkait dengan kesiapan tenaga kesehatan dalam perencanaan kehamilan pada wanita dengan HIV/AIDS.

\section{DAFTAR PUSTAKA}

Aishat, U., David, D. and Olufunmilayo, F. (2015) 'Exclusive breastfeeding and HIV/AIDS: a crossectional survey of mothers attending prevention of mother-to-child transmission of HIV clinics in southwestern Nigeria', Pan African Medical Journal, 8688, pp. 1-6. doi: 10.11604/pamj.2015.21.309.6498.

Kementerian Kesehatan RI (2014) Infodatin AIDS Pusat Data dan Informasi Kementerian Kesehatan RI. Jakarta.

Kementerian Kesehatan RI (2015) Pedoman Manajemen Program Pencegahan Penularan HIV dan Sifilis dari Ibu ke Anak, Kementerian Kesehatan RI. Jakarta: Kementerian Kesehatan RI.

Kementerian Kesehatan RI (2017) 'Laporan HIV/AIDS TW 4 Tahun 2017'. Jakarta. doi: 10.1109/CIE.2002.1185953.

Peters, P. J. and Brooks, J. T. (2018) HIV Infection, CDC Yellow Book 2018: Health Information for International Travel. Available at: https://wwwnc.cdc.gov/travel/yellowbook/2018/infectious-diseases- 
related-to-travel/hiv-infection (Accessed: 13 October 2018).

Rahmadona, Serudji, J. and Erwani (2014) 'Faktor-Faktor yang Berhubungan dengan Perilaku Bidan dalam Pencegahan Risiko Penularan HIV / AIDS pada Pertolongan Persalinan Normal di Kota Tanjungpinang Tahun', Jurnal Kesehatan Andalas, 3(3), pp. 506-516.

Sariningsih, O. and Yogisutanti, G. (2015) 'Pengetahuan Bidan tentang Deteksi Dini HIV AIDS pada Ibu Hamil dengan Implementasi Asuhan Kebidanan di Lahan Praktik', Midwife Journal, 1(2), pp. 45-51.

U.S. Departement of Health and Human Sevices (2017) The Basics of HIV Prevention: Understanding HIV/AIDS. Available at: https://aidsinfo.nih.gov/understanding-hiv-aids/fact-sheets/20/48/thebasics-of-hiv-prevention (Accessed: 31 October 2018).

World Health Organization and UNICEF (2016) Guideline Updates on HIV and Infant Feeding. Available at: https://apps.who.int/iris/bitstream/handle/10665/246260/9789241549707eng.pdf?sequence=1 (Accessed: 21 July 2019). 